on 7 Sept.; the year Dr. Loserth gives reasons for believing to be 1413. It affords further evidence of the intercourse between England and Bohemiz, since Oldcastle speaks of having heard by letter from Hus and others of the king's continued attachment to the reformers.

Reginald L. Poole.

\title{
A CONTEMPORARY ORATION ON POPE ALEXANDER VI.
}

ON 16 Sept. 1503 Burchardus records in his diary that Alexius Celadenus or Celadonius, bishop of Gallipoli, delivered a discourse to the cardinals about to enter into conclave for the election of a successor to Pope Alexander VI. Et fuit tediosa et longa oratio. Burchardus's most recent editor, Thuasne, states that this oration exists in manuscript in the Bibliothèque Nationele, and adds, Bien qu'il ne soit pas dépourr'u d'une certaine habilcté, vu la difficulté dis sujet, sa lecture confirme pleinement les épithìtes de Burchard. He omits to observe that, granting that the discourse may have been too long for the cardinals, the longer the better for us, inasmuch as it contains an account of Pope Alexander of almost unique value, not merely as the judgment of a contemporary, but as delivered in public before an audience of contemporaries, whose station in the church had brought then into almost daily intercourse with the decessed pope, and before whom any serious misrepresentation would have been impossible. It is incomprehensible how he should have failed to reprint an historical testimony of such importance, having it under his own eyes. Fortunately the omission can be repaired by favour of a circumstance unknown to him and to all other writers on the Borgias-the existence of the oration in print. It was printed, no doubt immediately after its delivery, without specification of place or the printer's name, but, as would appear by the type in Rome, and the only copy known to have occurred hitherto has just been purchased by the British Museum.

No startling novelty is to be looked for in the remarks of Celadenus, although some minor facts of interest come to light. Their value consists in the full confirmation of the sane and impartial view of Alexander taken by the bishop of Peterborough, and their refutation alike of the modern Roman catholic apologists who have endeavoured to rehabilitate the pope's moral character and of the depreciatory estimate of him as a sovereign formed by Villari, Gregorovius, and other modern writers of liberal prepossessions. Celadenus is, on the one hand, obviously acquainted with the existence of crimes and grave scandals, which he cleverly avoids enumerating, by assuming their universal notoriety. The remainder of his oration, moreover, is fall of oblique reflections upon the defurct pope, and exhortations regarding the choice of a successor which 
would be nonsensical if the late pontificate were not regarded as atterly disastrous in a spiritual point of view. At the same time it sufficiently attests the impression which Alexander had produced upon his contemporaries. The vastness of his designs, the vigour of his actions, a certain geniality and magnanimity in his nature, the promptitude of his resource and the persuasiveness of his eloquence, above all his astonishing fortune, still awe the speaker's imagination and rake his criticism almost a panegyric. It may be added that the circamstances under which the discourse was delivered were singularly conducive to impartiality. The fortunes of the house of Borgis still hung in the scale, too unpromising to tempt a flatterer, nor as yet sufficiently depressed to encourage a libeller. Celadenus's oration must reflect the generul sentiment with a fidelity unusual in compositions of its kind. The portion immediately concerning Alexander VI is as follows:-

Nascitur Alexender Velentiae regni pulcherrima et nobilissima sedo sub Alfonso Valentinorum et Aragonum clarissimo ac potentissimo Rege, Borgiarum familia splendida ut audio et illustri. Patriis deinde moribus a yarentibus educatus et institatus, Bononiam in Italiam ad bonas artes et leges sacras capessendas transmittitur, sub cura et opere avanculi tum Cardinalis Valentini postea Callisti tertii papae, a quo rogatus et non zninus sus sponte motus Nicenus, quem honoris et reverentiae gratia nomino, tunc Bononize legatus, ad bonos eum mores et studia saepissime hortabatur. $\mathrm{Ab}$ avanculu vero in pontificatum assumpto post paululum in sacrum Cardinalium senatum asciscitur, et Valentinae ecclesiae praesulatu donatur. Brevi deinde tempore elapso in procancellarii magistratu Francisco Condelmerio Cardinali Engenii quarti nepoti succedit, quamque prius senator magnam sibi autoritatem vel adhuc iuvenis comparaverat, Cancellariae magistratum adeptas plurimum iam in curis valere incepit. Et ut erat ad haec maxime eccommodato ingenio in creandis sui temporis pontificibus quos sibi profuturos prospiceret, plurimum iis opere exhibebat, unde nunquam presbyter a diacono praesul est factus. Legationes utriusque Hispaniae prius et deinde regni quoque Neapolitani ornandae diademate Reginne Iohannae gratia gessit. Maltos suae gentis Hispanique nominis auxit, et in primis domesticos, quibus modo magistratus anlicos modo sacerdotin condonabat. Pontificatum vero quasi expectatum et procuratum adeptus, tam magna atque ampla ab ipso statim ingressu agitare incepit ut et Alexandri nomen relicto pro more Roderici sibi indiderit, et orbem ipsum christianum quomodo undique commovere potuisset consilium cepisse a quibusdam indicaretur; et sane non modo contiguas sed partes quoque remotissimas movit. Noritati ac magnitudini rerum usque adeo studuit at nihil magis appetiikse videatur quam quomodo ostendisset nibil sibi vel a legibus vel a natura vel a Deo denegatum fuisse. Ft plane signa fortuita ris in rebus humanis est, et ea quam fortunam prisci, nobis pio vocabulo permissionem Dei vocare licet, reperitur, tam secunda et perpetua usus est ut nihil eo fortnnatios existimes fieri potuisse, quo fiebat ut non secus quam ex sententia cuncta sibi successura susciperet. Siquid vero adversi passus fuisset, cam de prosperis despe- 
raret, de repente plus quam vel ipse optare potuisset consequebatur. Naufragio facto plurimis bonorum comitumque amissis ipse evasit. Pestilentia correptus adhuc juvenis praevalnit. Per vim falguris tecti praegrandis et alti et duorum oneratissimorum tabulatorum ruinis senex oppressus ef capite ao corpore concassatus intra nonum et vigesimum diem ad divae Mariae de populo quam praecipue renerabatur solvendi voti gratia est lectica evectus. Ita et maris et terrae et coeli discrimina superabat. In convivando splendidus, in aedificando magnificus fuit, at ex aedibus eius nondum pontificis et ex urbana Nepesina Vuentana et aliis arcibus et turri ex ejus cognomine in aedibus Vaticanis et templi sanctae Mariae in praesepe sive Majoris laquearibus colligere licet. Ingenio quidem tam acri et callido fuit ut et àlios ante se ad pentificatum inverit et post modum se quoque ipse vel adversantium suffragiis raluerit erexisse. Animo vero ad vastitatem magno. Cam suis, etsi plurimum eis indulserit, sui tamen inris fuit, in eos slioquin adeo beneficus ut plares ipse in Cardineam dignitatem provexerit quam alius annis totidem in praesulatum vocasset. A subiectis timeri quam amari malebat: ignarus credo ut homo amore imperia et diatius retineri et farilius guberuari, timore praepropere admodum corruere. Memoria tam tenaci erat at in signandis libellis quas supplicationes vocant vel minimas particulas annis non pancis interlapsis memoraret. In re divina tam concinnus et aptus ut nec iis cederet qui hoc unice profitentur, unde cerimoniis quoque intentissimus erat. Ad risum tam multus et facilis, ut sicut animos sibi conciliabat, ita maiestatem quam retinere nitebatur, paulisper plerumque relaxaret. Sermone fuit usque adeo suavi et blando, at sicut nibil sibi denegari efficiebat, ita, in tanta dignitate pontificia praesertim, minus decorum servaret. Quid plura? adeo et sermone et ingenio confidebat, ut videretur non quid aggrediendum sed quid cupierdum cogitare. Unde tantam anri vim in pontificatn collegit, quantam nec ipse fortassis si vireret rationem reddere posset. Forms etiam oris proceritateque corporis, at nostis, egregia fuit. His autem naturae fortanaeque dotibus quomodo usus fuerit, quid apud ros attinet dicere, qui bene et fortasse melius nostis? Habet enim hoo etiam infelicitatis principatus, quod in excelso positus nilil celare potest. Illud certe utilitatis ab Alexandro Pontifice provenisse facile affirmaverim, quod cum annis XI vixerit, et multa et varia gesserit, immensamque pecuniam in bellis gerendis et aliis diversis sumptibus erogaverit, ad extremum vero annum agens quartum et septuagesimum, dum graviter regrotaret, factorum conscientia punctus contrito dolentique animo ad lachrymas at audio fusus, sacrosanctum communionis corpus sua spontc, dilutis prius diligentissima confessione peccatis, petierit, et alia sacramento singilatim quaesita perceperit : satis et ros quid nunc agere debeatis, et successorem a quibus abstineat quaeque agere debeat docuisse videtur. Pro quo et pro charitatis debito oro omnes atque obtestor ut eum piis crebrisque precibus Dei clementiae commendemus. Nos miseros mortales vere infelices atque insanos, qui quanto plus vivere cupimus, tanto plus insanire velle videmur! Ecce Alexandram tam prospera valetudine in toto corpore hominem, non imbecillem, non decrepitam, sed longioris vitae spe plenum, eaque animo concipientem vel gerentem quae vix annis pluribus compleri potnissent, quatriduana febris e medio abstalit et sors de repente extinxit. Me me miseram! quem paulo ante sublimem in 
sede illa majestatis vectum, stipatam militibus, vivacem valtus et vigorosum, vix intueri vel suspicere proni proclivesque homines rel propius accedere audebant, eum diebus his homili feretro iacentem, turpem, putidum, et usque ad horrorem deformem, peropposite sublimis ego e primis gradibus inferiorem inspexi, sed neo id prae horrore potui diatius sustinere.

Alexius Celadenus was a Spartan of noble birth, as apperrs by his epitaph, and he implies in this oration that he had enjoyed the favour of his illustrious countryman Cardinal Bessarion. He had been made bishop of Gallipoli in 1494, and is frequently mentioned by Burchardus as participating in ecclesiastical ceremonies. He had previously delivered a funzral oration on Alexander's predecessor Innocent VIII, a copy of which is in Earl Spencer's library; another was formerly in the possession of Count Bossi, the translator of Roscoe. He was translated to Molfetta in 1508, and died bishop of that see in 1517, aged 67. He was buried in the church of St. Augustine at Rome, with an epitaph describing him as geminae linguac orator et interpres acutissimus, and religione et sanctis semper operibus admirabilis. ${ }^{1}$

R. Garnett.

\section{$\triangle$ REPORT ON THE CONDITION OF PERgIA IN THE YEAR 1586.}

DN 16 Jan. 1588-89, Hieronimo Lippomano, Venetian ambassador at Madrid, enclosed the following report on Persia in a despatch to his government. The report was compiled by Giovanni Battista Vechietti at the command of Pope Gregory XIII, who sent Vechietti to Persia for the purpose. At Aleppo, Vechietti heard that Pope Gregory had died; his successor renewed the commission at the instance of the Cardinal de' Medici, and Vechietti continued his journey. The report contains a minute account of the kingdom of Persia, its forces, and its revenues, and a statement regarding the island of Ormuz. A copy was presented to the king of Spain; and the ambassador's secretary, Marchesini, succeeded in surreptitiously obtaining a transcript, which Lippomano sent to Venice. He begged the government to use all vigilance in preserving the document secret, as the suspicion that the contents were known to others would seriously injure the person who had communicated it.

\section{Horatio F. Brown.}

\section{Lettera. Sacra Cattolica Real Maestd.}

Havendo io a dar relatione alla Mresti Vostra del negotio trattato da me in Persia, lesciate adietro le cose superflue farò un breve ristretto delle più importanti, et degne di esser saputo da lei; distinguendo il mio ragionamento in quattro capi. Il primo sard esporre, con che commissione io fai mandato a quel Re, et che risposta ne habbia ritratto; Il secondo dello stato nel quale ho trovato, et lasciato quel Regno; Il terzo 